$12-1-1969$

\title{
False or Suppressed Evidence: Why a Need for the Prosecutorial Tie?
}

Ronald L. Carlson

University of Georgia School of Law

S

\section{Repository Citation}

Ronald L. Carlson, False or Suppressed Evidence: Why a Need for the Prosecutorial Tie? (1969),

Available at: https://digitalcommons.law.uga.edu/fac_artchop/377

This Article is brought to you for free and open access by the Faculty Scholarship at Digital Commons @ University of Georgia School of Law. It has been accepted for inclusion in Scholarly Works by an authorized administrator of Digital Commons @ University of Georgia School of Law. Please share how you have benefited from this access For more information, please contact tstriepe@uga.edu. 


\title{
FALSE OR SUPPRESSED EVIDENCE: WHY A NEED FOR THE PROSECUTORIAL TIE?
}

\author{
Ronald L. Carlson* \\ "Decency, security and liberty alike demand that government \\ officials shall be subjected to the same rules of conduct that are \\ commands to the citizen. In a government of laws, existence of the \\ government will be imperilled if it fails to observe the law \\ scrupulously. Our government is the potent, the omnipresent teacher. \\ For good or for ill, it teaches the whole people by its example." \\ -Mr. Justice Brandeis $†$ \\ "We know that a trial based on false or suppressed evidence is no \\ trial at all. False or suppressed evidence can neither convict nor \\ condemn." \\ -United States ex rel. \\ Hough v. Maroneytf
}

Many United States Supreme Court decisions have overturned criminal convictions for the reason that the government employed false evidence to obtain the conviction or failed to disclose relevant evidence important to the defense. In reversing federal or state judgments, the Court often has located direct proof of wrongdoing by the prosecutor. The notorious "bloody shorts" case is an example in point." There, the state introduced as evidence a pair of men's "blood-stained" undershorts to achieve conviction of the accused. When the blood turned out to be red paint, the Supreme Court granted habeas corpus relief to the defendant because "[i]t was further established that counsel for the prosecution had known at the time of the trial that the shorts were stained with paint. . . The prosecution deliberately misrepresented the truth."'

\footnotetext{
* Professor of Law. University of lowa College of Law. B.A. 1956. Augustana College; J.D. 1959. Northwestern University: LL.M. 1961, Georgetown Law Center (E. Barrett Prettyman Fellow in Trial Advocacy). The author served as counsel for the petitioner in Johnson v. Bennett. 393 U.S. 253 (1968), which raised certain issues analogous to those explored in this article. The case was resolved in the Supreme Court on another point.

tOlmstead v. United States. 277 U.S. 438. 485 (1928) (dissenting opinion).

t+247 F. Supp. 767.779 (W.D. Pa. 1965).

'Miller v. Pate. 386 U.S. 1 (1967).

2/d. at 6 . $\cdots$ In the. Viller case, the Court found that the prosecutor at the time of trial knew the incriminating shorts were stained with paint and the stains were passed off at trial as blood stains," Johnson v. Bennett, 386 F.2d 677. 680 (8th Cir. 1967), vacatct. 393 U.S. 253 (1968).
} 
Judicial opinions in this area of the law have frequently emphasized the prosecutor's historic duty not to convict but rather to do justice. Violations of this duty by the state's prosecuting officer can create constitutional problems of verdict-rupturing magnitude: "It is as much his duty to refrain from improper methods calculated to produce a wrongful conviction as it is to use every legitimate means to bring about a just one."3

That deliberate evidence-suppressing conduct by the prosecutor voids a conviction is clear. But the problem becomes more difficult when the hiding of documents or witnesses is accomplished not by the prosecutor but by a lower-ranking minion of the state. What if a police officer discovers important evidence which is helpful to the defendant and fails to call it to the attention of either the prosecutor or the defense?

To explore the practical impact of such problems it is helpful to pose an illustrative situation. A police detective in the course of a homicide investigation seizes a pistol from the accused. At trial several witnesses testify that the gun looks exactly like the murder weapon. The accused is convicted. However, unknown to the attorneys in the case the police detective had a ballistics test run on the gun shortly after its seizure which demonstrated that the pistol had not been fired for several months. Thus, it could not have been the murder weapon. ${ }^{4}$ Ultimately the defense learns of the ballistics report. The question next comes: Does the judgment of conviction remain intact in consequence of the fact that the prosecutor was unaware of crucial defense evidence held by the police?

If the answer to the above inquiry appears obvious, consider a 1967 United States Court of Appeals proclamation on the subject:

So far as we have been able to ascertain, all the Supreme Court cases setting aside convictions for want of due process by reason of the reception of false testimony are based upon knowledge of the prosecutor that the testimony received is false or knowledge that material evidence has been suppressed. Such would appear to be a proper limitation of the rule.

revd. 414 F.2d 50 (8th Cir. 1969). Civil actions against prosecutors who suppress or falsify evidence are discussed in Comment. tatioms Igains Prosectutors Who Stupress or Falsifi. Fividence. 47 Texas L. Rev. 642 (1969).

${ }^{3}$ Berger v. United States, 295 U.S. 78, 88 (1935). S'(' Jackson v. Wainwright, 390 F.2d 288, 294 (5th Cir. 1968): A BA Canons of Professional Ethics No. 7, Ethical Consideration 7-13.

'The example posed here resembles the fact pattern presented the federal court in Barbee $v$. Warden, 331 F.2d 842 (4th Cir. 1964), a case involving suppressed ballistics reports in a prosecution for felonious assault.

sJohnson v. Bennett, 386 F.2d 677, 680 (8th Cir. 1967), vacaled. 393 U.S. 253 (1968), rel'd. 
Strictly applied, this rule would prevent the homicide conviction posed above from being overturned on appeal or in habeas corpus. Absent knowledge by the prosecutor himself of the ballistics report, a police officer's misconduct in suppressing relevant evidence would be insufficient to invalidate the conviction. Other courts have displayed a decided reticence to overturn convictions without proof of complicity by the prosecutor in the wrongdoing. Such proof is frequently hard to come by, leaving open major issues in these cases: Does the conduct of a police officer in suppressing evidence constitute state action which deprives a conviction of its due process base, assuming such suppression is eventually discovered? In the false evidence cases, can a defendant who was condemned by perjured testimony successfully attack his conviction even though he lacks proof of governmental connivance in the perjury? In dealing with these issues this article explores the question of whether the Due Process Clause is addressed to the prosecutor alone, or applies as well to police and others who may traffic in suppressed or false evidence.

\section{SUPREME COURT Decisions}

Supreme Court opinions treating the problems of false and suppressed evidence extend across 35 years of Court history. ${ }^{7} \mathrm{~A}$

414 F.2d 50 (8th Cir. 1969) (emphasis added). At another point in the decision, the court refused to invalidate the state court conviction of the prisoner under his contention that a county "sheriff had falsified the return on a subpoena issued for a defense witness. The court stated: "The record indicates that the prosecuting attorney had no knowledge of the falsity of the return, and defendant as a witness states that he has no evidence to the contrary." Id. at 681. See the analysis of Luna v. Beto, 395 F.2d 35 (5th Cir. 1968), cert. denied, 394 U.S. 966 (1969), note 20 infra. See also Hysler.v. Florida, 315 U.S. 411, 419,421 n.4 (1942).

'See. e.g. Hysler v. Florida, 315 U.S. 411, 419, 421 n.4 (1942); Green v. United States, 313 F.2d 6, 8 n.2 (1st Cir.), cert. denied. 372 U.S. 951 (1963); United States v. Lawrenson, 298 F.2d 880, 888 (4th Cir.), cert. denied. 370 U.S. 947 (1962); United States v. Jakalski, 237 F.2d 503, 504-05 (7th Cir. 1956), cert. denied, 353 U.S. 939 (1957) (“The introduction of perjured testimony without more does not violate the constitutional rights of the accused. It is the knowing and intentional use of such testimony by the prosecuting authorities that is a denial of due process of law."); Taylor v. United States, 229 F.2d 826, 829, 832 (8th Cir.), cert. denied. 351 U.S. 986 (1956) (perjured testimony does not void a conviction unless prosecuting officials knew at the time testimony was used that it was perjured); In re Sawyer's Petition, 229 F.2d 805, 809 (7th Cir.), cert. denied. 351 U.S. 966 (1956) ("Sawyer's Federal Constitutional rights were not denied unless perjured testimony was introduced with the knowledge of the prosecutor that it was perjured."). See also Mareella v. United States, 344 F.2d 876, 880 (9th Cir. 1965), cert. denied, 382 U.S. 1016 (1966); Tilghman v. Hunter, 167 F.2d 661, 662 (10th Cir. 1948); Note, A Fresh Look at the Suppressed Evidence Rule. 34 BROOKLYN L. REV. 269 (1968).

'Supreme Court decisions which deal with the false-suppressed evidence problem in criminal 
significant recent treatment of the suppressed evidence question is the Court's 1967 decision in Giles v. Maryland, 8 a case which involved petitioners originally convicted of rape and sentenced to death. Serious questions later arose concerning whether police reports which contained statements of the prosecutrix inconsistent with her trial testimony had been disclosed to the defense. ${ }^{9}$ These reports were highly relevant in terms of assessing the credibility of the state's chief witness in a case wherein credibility was a crucial factor. ${ }^{10}$

Although the plurality opinion in Giles avoided laying down broad constitutional rules for disclosure of evidence, the rationales of the concurring and dissenting opinions focused on the prosecutor's obligation to disclose information to the defense. Under the view expressed in the concurring opinion of Mr. Justice Fortas, disclosure should be made of all evidence which, generously conceived, is material to the case." Mr. Justice Harlan, writing the dissent, pointed out that the standard developed in certain Supreme Court cases required prosecutorial disclosure only of items which may affect the outcome of the trial. ${ }^{12}$

Amid the controversy over appropriate standards for the guidance of prosecutors, it is the concurring opinion of $\mathrm{Mr}$. Justice White which highlights for future consideration a major question posed in this article. The White opinion raises the problem of

prosecutions include United States v. Augenblick. 393 U.S. 348 (1969): Giles v. Maryland. 386 U.S. 66 (1967); Miller v. Pate. 386 U.S. 1 (1967): Brady v. Maryland. 373 U.S. 83 (1963): Wilde v. Wyoming, 362 U.S. 607 (1960); Napue v. Illinois, 360 U.S. 264 (1959): Alcorta v. Texas, 355 U.S. 28 (1957); Mesarosh v. United States. 352 U.S. I (1956): Griffin v. United States, 336 U.S. 704 (1949): White v. Ragen. 324 U.S. 760 (1945): New York \&x r(l. Whitman v. Wilson, 318 U.S. 688 (1943); Pyle v. Kansas, 317 U.S. 213 (1942): Hysler v. Florida. 315 U.S. 411 (1942); Mooney v. Holohan, 294 U.S. 103 (1935).

In the non-criminal field, the Court's treatment of the problem appears to date to be United States v. Throckmorton, 98 U.S.61 (1878).

386 U.S. 66 (1967).

Id. at 80 .

${ }^{10} I d$. at 70 . Also noted by the Court was the possible bearing of the reports on the busic question of guilt or innocence. Id. at 77 .

"Jd. at 98.

12Jd. at 116. Controversy over what type of nondisclosure rises to the level of a due process violation continues. See United States v. Acarino, 408 F.2d 512 (2d Cir.). ،'‘rl. dinhlud. 395 U.S. 961 (1969), which posed the following question to the Supreme Court: Was due process violated by a prosecutor's failure to inform the court or defense counsel that a key prosecution witness was under indictment for larceny. S'(' alsu Nash v Illinois, 389 U.S. 906 (1967) (denial of certiorari; Fortas. J.. Warren. C.J.. \& Douglas. J.. dissenting); Crowder v. United States, 406 F.2d 727 (6th Cir. 1969): Nash v. Purdy. 283 F Supp. 837.842 (S.D. Fla. 1968): Vessels v. State. 432 S.W.2d 108. 110. 114 (Tex. Crim. App. 1968). 
attributing the conduct of other persons to the prosecutor, the prosecutor in this instance being thc State's Attorney for Montgomery County, Maryland. Voting to remand the Giles case to the Maryland Court of Appeals, Mr. Justice White concluded:

There is another matter for the consideration of the Maryland court: the prosecuting attorney of Montgomery County was not charged with the knowledge of Prince George's County officers but he was charged with what the police officers of Montgomery County knew. Was he also charged with the knowledge of other Montgomery County officials such as Lynn Adams, and, to the extent of their involvement with Montgomery County agencies, Dr. Connor and Dr. Doudoumopoulis? ${ }^{13}$

This passage arguably intimates approval of a rule which would charge a prosecuting attorney with knowledge possessed by a peace officer in the prosecutor's home county. A different case may be suggestcd where officers holding valuable exculpatory information or evidence are from another county of the state. Under one view, the knowledge of these latter officers may not be charged to the prosecutor, and apparently their failure to disclose the evidence would create no due process violation. As for attribution to the prosecutor of knowledge held by non-police officials, this question was left open in the White opinion.

The emphasis by Justice White in Giles on the relevant knowledge of police or other officials which may be charged to a prosecutor points up the pivotal position of the prosecuting attorney in these cases. Rather than focusing directly on the conduct of the

\footnotetext{
13386 U.S. at 96 (emphasis added). In State v. Giles, 239 Md. 458, 470, 212 A.2d 101, 108 (1965), the Maryland Court of Appeals held it reasonable to charge the prosecutor with relevant information known to the local police department, but that to go further would impose an "unworkable burden on local authorities." Such a judicial approach to the prohlem appears in the colloquy between the Court and petitioner's counsel in the argument of Johnson v. Bennett. 393 U.S. 253 (1968). There, the sheriff's office in a county of the state some 160 miles removed from the place of trial allegedly suppressed key evidence:

Q. (by one of the Justices) I take it the sheriff is unavailable?

A. (by counsel for the prisoner) Yes. He is deceased, Your Honor.

Q. Did you say this county was 160 miles from the trial county?

A. Yes.

Q. The prosecutor, 1 take it, is the official in the trial county?

A. Yes.

Q. Was there any evidence that the local sheriff in that county knew anything of this?

A. There is no evidence in the record, Your Honor, positive and clearcut. . . .

$*$ *

Q This question of knowing suppression of evidence ordinarily involves someone. such as a local police officer. who was responsible.

Record at 5-6. Johnson v. Bennett, 393 U.S. 253 (1968).
} 
police as a responsible arm of the state, some judicial authority analyzes the kind of police activity which may be attributed to an unknowing prosecutor: ${ }^{14}$ If the police suppression of evidence cannot be connected with the prosecutor under an agency theory, as may be the case when the suppression is achieved by out-of-county officers, the conviction is unassailable. That the Supreme Court has not specifically rebuffed this position is indicated by a review of relevant Court opinions and is further revealed in a recent appellate argument before the Court. ${ }^{15}$

Supreme Court cases in this area of the law overturning convictions on due process grounds almost invariably involve participation by the prosecutor in the wrongdoing. ${ }^{16}$ It is submitted that this coincidence of fact should not insulate from attack those convictions wherein the prosecutor has clean hands but which are nonetheless tainted by false or suppressed evidence emanating from

\footnotetext{
"See Imbler v. Craven, 298 F. Supp. 795,806 (C.D. Cal. 1969).

${ }^{15}$ See the questions raised by the Court during the argument in Johnson v. Bennett, 393 U.S. 253 (1968), set forth in note 13 supra. In the false evidence field, the view of one Justice as to the prior Court history on the point appears to be reflected in this question: "We have not yet' in this Court, have we, said if false testimony gets in that it is fatal to a conviction unless it got in with a knowledge of its falsity on the part of the prosecution?" Record at 42-43, Johnson v. Bennett, 393 U.S. 253 (1968).

"See. e.g.. Miller v. Pate, 386 U.S. 1 (1967) (Prosecutor held to have deliberately misrepresented the truth about a state's exhibit, both in evidence presentation and during argument to the jury); Brady v. Maryland, 373 U.S. 83 (1963) (due process violated when prosecution withheld co-defendant's confession after demand for same by the accused, although prosecutor's action was not the result of guile); Napue v. Illinois, 360 U.S. 264 (1959) (failure of the prosecutor to correct the testimony of a state witness which the prosecutor knew to be false denied the defendant due process of law); Alcorta v. Texas, 355 U.S. 28 (1957) (testimony which gave jury false impression elicited by prosecutor who knew facts to be to the contrary); White v. Ragen, 324 U.S. 760 (1945) (petitioner's allegation that prosecuting attorney bribed two state witnesses made out prima facie violation of fourteenth amendment) (dictum). Perhaps an arguable deviation from the text statement is Pyle v. Kansas, 317 U.S. 213 (1942). See the analysis of Pyle in Curran v. Delaware, 259 F.2d 707, 713 (3d Cir. 1958), cerl. denied. 358 U.S. 948 (1959). See also Durley v. Mayo, 35I U.S. 277, 291 (1956) (dissenting opinion).

Concentration by the Supreme Court on the prosecutor's role appears to have inclined the commentators to focus primary attention on this officer's dislcosure obligations. Limited treatment has been accorded the related problems explored in this article. See generall! 34 Brooxlyn L. Rev., supra note 6; Note, The Dut!' of the Prosecutor to Disclose Exculpator!' Evidence. 60 Colum. L. REv. 858 (1960); Comment, Disclosure and Discover! in Criminal Cases: Where are We Headed? 6 DuQuesNe L. Rev. 41 (1967); Comment, Criminal Discover.' Implications of the Faise Evidence and Suppression of Evidence Cases. 34 TENN. L. REv. 654 (1967); Note, The Prosecutor's Constitutional Dut! to Reveal Evidence to the Defendamt. 74 YALE L.J. 136 (1964); 77 HARV. L. REV. 1528 (1964); 42 N.Y.U.L. REV. 764 (1967); 42 Notre DAme Law. 264 (1966).
} 
a different source. A broader emphasis is urged. In the suppressed evidence cases, rather than searching for an agency rationale or other devices to "charge" the prosecutor with knowledge held by others, a state action concept is suggested to cover all law enforcement officers in the state.

\section{Federal and State Cases: Posture of the Current Law}

Three problem areas are typically presented in these cases: (1) a policeman in the same locality as the prosecutor suppresses relevant proof; (2) the police in another-locality suppress potential defense evidence; (3) false evidence is injected into the trial of the case by a private citizen, not a policeman. Each presents different levels of inquiry, and various approaches employed by disparate courts provide the framework for analysis.

\section{Suppression of Evidence: Local Police}

The geographical area over which a prosecutor has jurisdiction is generally a county or district, ${ }^{17}$ and prosecutors frequently have been held responsible for peace officer suppressions within their "territory." Barbee v. Warden, ${ }^{18}$ a leading authority on this issue, makes the point: "The police are also part of the prosecution, and the taint on the trial is no less if they, rather than the State's Attorney, were guilty of the nondisclosure."19 Notwithstanding occasional judicial comments to the contrary, ${ }^{20}$ the point seems so

\footnotetext{
"Movement toward district attorney systems is reported in PrEsident's CoMmission oN Law Enforcement and the administration of Justice, Task force Report: The COURTS 74 (1967).

12331 F.2d 842 (4th Cir. 1964).

"Id. at 846. See also Nash v. Purdy, 283 F. Supp. 837, 841 (S.D. Fla. 1968); State v. Giles, 239 Md. 458, 470, 212 A.2d 10I, 108 (1965), vacaled. 386 U.S. 66 (1967).

"United States v. Lawrenson, 298 F.2d 880, 888 (4th Cir.), cert. denied. 370 U.S. 947 (1962). The recent case of Luna v. Beto, 395 F.2d 35 (5th Cir. 1968), cert. denied. 394 U.S. 966 (1969), is summarized in Note, Police .Yot Obligated to Disclose Facts Unknown to Prosecutor, 1969 L. \& SOCIAL ORDER 297:

Luna presented squarely one of the major ambiguities in the line of decisions. It is clear that the prosecutor has a duty to reveal information that bears on the accuracy of testimony or evidence presented during trial. But. if the prosecuting attorney has no knowledge of information that he would have to disclose if it were in his possession, is a conviction constitutionally defective because of failure on the part of police officers in possession of this information to initiate steps to see that defense is aware of its existence? According to the en banc court in Luna. the answer is no. Although the court advanced a number of reasons for refusing to hold the conviction invalid, the opinion makes clear that heavy reliance was placed upon the fact that the police officers with
} 
well established today that a recent federal opinion terms this principle "no longer subject to serious dispute."21

What is more difficult is whether the reviewing court must weigh the potential force of the suppressed evidence, testing the probable admissibility of the hidden proof, contemplating its possible effect on the outcome of the trial. Such hindsight testing is regularly employed when the prosecutor has neglected his duty to call significant evidence within his knowledge to the attention of the defendant. ${ }^{22}$ ln order to overturn a conviction under this rationale, most courts insist that the convicted party demonstrate the materiality of the suppressed evidence. ${ }^{23}$ The reasons for placing this burden on the appellant were identified by Judge Henry J. Friendly in United States' $v$. Keogh $h^{24}$ as "the avoidance of impossible burdens on prosecutors and the need to preserve the finality of convictions . . ."25

knowledge that charges had been brought were not in the courtroom at the time that the witness gave the incorrect testimony. Id. at 302-03.

${ }^{21} 1$ mbler v. Craven, 298 F. Supp. 795, 806 (C.D. Cal. 1969). Seu Augenblick v. United States, 377 F.2d 586, 598 (Ct. Cl. 1967), rev'd. 393 U.S. 348 (1969); Curran v. Delaware. 259 F.2d 707 (3rd Cir. 1958), cert. denied. 358 U.S. 948 (1959); Nash v. Purdy, 283 F. Supp. 837, 841 (S.D. Fla. 1968); People v. Robertson, 12 N.Y.2d 355, 190 N.E.2d 19 (1963); Note, Discover. in Massachusetts Criminal Proceedings- 4 Survel of trailable Devices aud l'th Trends. 2 Suffolk L. Rev. 272, 286-87 (1968); 34 TENN. L. REV.. supra note 16, at 660-63: 42 N.Y.U.L. REv. 764, 766 n.20 (1967).

zUnited States v. Keogh, 391 F.2d 138, 147 (2d Cir. 1968).

¿See. e.g.. Brady v. Maryland, 373 U.S. 83 (1963). "[T] he suppression by the prosecution of evidence favorable to an accused upon request violates due process where the evidence is material either to guilt or to punishment, irrespective of the good faith or bad faith of the prosecution." Id. at 87; United States v. Polisi, 416 F.2d 573 (2d Cir. 1969): United States v. Tomaiolo, 378 F.2d 26 (2d Cir.). cert denied. 389 U.S. 886 (1967); Kyle v. United States. 297 F.2d 507 (2d Cir 1961): United States v Consolidated Laundries Corp.. 291 F.2d 563 (2d Cir. 1961).

2439I F.2d 138 (2d Cir. 1968).

${ }^{25} / d$. at 146 . The opinion points out that the question of whether a conviction should be overturned generally arises in a habeas corpus proceeding as opposed to direct appeal 34 BROOKLYN L. REV.. supra note 6, at 270 n.9. Perhaps this is because facts sustaining the suppression claim frequently do not come to light until well after original trial of the case. In any event, numerous cases void convictions in habeas corpus without implying that any higher standard of proof will be exacted than if the defendant were seeking to overturn the conviction on direct appeal. However, the Keogh decision does draw a distinction between habeas corpus and coram nobis proceedings. With the latter, in the absence of proof of deliberate prosecutorial misconduct, relief will be granted only when the court concludes that the undisclosed evidence probably would have raised a reasonable doubt of guilt in the mind of a juror. The heavy.evidentiary burden placed on a defendant in coram mobis cases is based upon the lower incidence of reprosecution and retrial when convictions are voided in ('oram nohis 391 F.2d at 148. Further qualifications are added in footnote 9 to the Ke'ogh opinion. Il at 
To appreciate these grounds it is necessary to understand that suppression of evidence today connotes two distinct types of prosecutorial conduct. In the older cases evidence was suppressed when the prosecutor deliberately hid evidence important to the defendant. ${ }^{26}$ Current law also includes as suppression any prosecutorial failure to disclose evidence which the defendant could have put to important use, even though no defense request for the evidence was made. ${ }^{2 \pi}$ In the latter class of cases; termed passive nondisclosures by many courts, the undisclosed evidence must be highly material in order for the defense to successfully attack the conviction. ${ }^{28}$ This is not so with deliberate suppression by the prosecutor, however. Courts promptly overturn judgments tainted by deliberate wrongdoing in order to deter conduct which is detrimental to the integrity of the judicial process. Actual materiality of the suppressed evidence is of limited importance in such cases. ${ }^{29}$

But, do or should these evidence testing rules operate in similar fashion where the police alone are proved responsible for the suppression, without prosecutorial complicity? It would appear that no meaner standards should be applied to police suppression. When a police officer misrepresents the whereabouts of a defense witness

148-49. For standards in connection with motions for new trial based upon false evidenee, see cases cited notes $43-44$ intiro.

* (\%. 391 15.2d at 148:

Deliberate prosecutorial misconduct is presumably infrequent: to invalidate convictions

in the few cases where this is proved. even on a fairly low showing of materiality, will

have a relatively small impact on the desired finality of judgments and will deter conduct undermining the integrity of the judicial system. Id.

تS're Jackson v. Wainwright, 390 F.2d 288 (5th Cir. 1968); Levin v. Katzenbach, 363 F.2d 287 (D.C. Cir. 1966). Both of these cases provide excellent collections of authority in the falsesuppressed evidence fields. Siv a/s) Hamric v. Bailey, 386 F.2d 390 (4th Cir. 1967); United States v. Poole. 379 F.2d 645 (7th Cir. 1967); United States ex rel. Meers v. Wilkins, 326 F.2d 135 (2d Cir. 1964).

- Under one view, such evidence must raise a high probability that disclosure thereof to the defense would have altered the result in the trial of the case. United States v. Keogh, 391 F.2d 138. 148 (2d Cir. 1968). S'(' also Ingram v. Peyton, 367 F.2d 933, 936 (4th Cir. 1966); Link v. United States. 352 F.2d 207 (8th Cir. 1965), cert. dented. 383 U.S. 915 (1966); Smallwood v. Warden. 205 F. Supp. 325. 329 (D. Md. 1962). In a very recent case, the Second Circuit ruled that undisclosed evidence was material and a new trial required even though the suppressed evidence probably would not have produced a different verdict. United States $v$. Polisi, 416 F.2d 573, 578 (2d Cir. 1969).

"Sic' United States v. Acarino, 408 F.2d 512, 516 (2d Cir.), cert. denied. 395 U.S. 961 (1969); (\%. Kyle v. United States, 297 F.2d 507, 514 (2d Cir. 1961); Note, Individualized ('riminal Justice in the Supreme Court: -t Study of Dispositional Decision Making. 81 HARv. L. REv. 1260, 1273-75 (1968). 
or threatens such witness, causing him to be absent from the trial of the case, any conviction obtained by the state should be overturned without extensive inquiry into whether the testimony of the witness would have changed the outcome. ${ }^{30}$ However, courts have not uniformly applied the prosecutorial standard to police misconduct, and some authorities demand a showing of materiality of the suppressed evidence even in deliberate suppression cases. ${ }^{31}$ It

\footnotetext{
${ }^{30} \mathrm{As}$ in the prosecutor cases, such deliberate police conduct is not ordinary. Still, such instances occasionally occur. See Johnson v. Bennett, 386 F.2d 677 (8th Cir. 1967), vacaled. 393 U.S. 253 (1968), rev'd, 414 F.2d 50 (8th Cir. 1969), wherein the petitioner alleged that a sheriff charged with the duty of serving subpoenas on defense witnesses locked up one of the witnesses and reported that the witness was in an "Institute for lnsane." The United States Court of Appeals for the Eighth Circuit reviewed the record:

By the reason of defendant's poverty, the court directed that certain witnesses, including Thomas Orcussi, be subpoenaed for the defendant at State expense. The sheriff at Burlington [lowa, the place of trial] assumed responsibility for the service of such subpoenas by sending them to the sheriff of Polk County [165 miles away] for service upon the witnesses residing in Des Moines. With respect to Orcussi, the subpoena was returned unserved with the notice. "Thomas Orcussi is in Clarinda Institute for. Insane." No further attempt was made to secure Orcussi, apparently in reliance upon such statement, and Orcussi did not appear as a witness at defendant's trial.

In the present proceeding, the Polk County jail records were introduced in evidence and they disclosed that Orcussi was in the Polk County jail serving a thirty-day sentence for intoxication during the period the subpoena was in the hands of the Polk County sheriff for service. The jail records show nothing with respect to the transfer of Orcussi to a mental hospital. The trial court in its opinion observes that his independent investigation discloses that the records at the Clarinda Institution do not show that Orcussi was ever received at such institution. Such evidence establishes a prima facie case that the return of the Polk County sheriff is false. No explanation has been made by the State. Fairness requires an observation that persons who might be in a position to explain the return are no longer available. The record indicates that the prosecuting attorney had no knowledge of the falsity of the return, and defendant as a witness states that he has no evidence to the contrary. Id. at 680-81.
}

Cases which involve the problem of police/prosecutor suppression or intimidation of witnesses include Turner v. Ward, 321 F.2d 918 (10th Cir. 1963); United States ex rul. Montgomery v. Ragen, 86 F. Supp. 382, 391 (N.D. 111. 1949) (the States Attorney by threats of intimidation prevented any witnesses from testifying in behalf of James Montgomery); People v. Garippo, 321 11l. 157, 163, 151 N.E. 584, 586 (1926); Davis v. State, 200 Ind. 88, 102-06, 161 N.E. 375, 380-82 (1928); Hudson v. Commonwealth, $220 \mathrm{Ky}$. 582, 295 S.W. 886 (1927). See E. Hopkins, Our Lawless Police 280-82 (1931); National Commission on LaW OBservance and ENforcement, Report on LAWLessness IN LAW ENFORCEMENT 284 (1931) (Wickersham Report). Where the suppression of evidence involves frustration of the defendant's subpoenas for defense witnesses, a violation of the sixth amendment right to compulsory process to secure witnesses may coalesce with a suppression of evidence claim. See Barton v. Wainwright, 412 F.2d 229 (5th Cir. 1969). That the right to compulsory process includes the right to service of that process, see Brewer v. Hunter, 163 F.2d 341, 342 (10th Cir. 1947); State v. Copola, 157 La. 98,102 So. 82 (1924).

${ }^{31}$ E.g.. Johnson v. Bennett, 386 F.2d 677, 681 (8th Cir. 1967), vacaled. 393 U.S. 253 (1968), rev'd. 414 F.2d 50 (8th Cir. 1969), discussed note 28 supra. 
is urged that convictions involving deliberate suppression of evidence should be readily overturned on a very low showing of materiality. Deliberate suppression of evidence by police is as destructive, and as much merits deterring, as similar conduct by a prosecutor.

\section{Officers Outside the Prosecutor's District}

The state court decision in State $v$. Giles ${ }^{32}$ posits one view-misconduct of non-local officers cannot be imputed to the trial prosecutor. "In order to decide what evidence can be said to have been suppressed it is first necessary to determine what the prosecution was charged with knowing." 33 The decision holds it appropriate "to charge the prosecutor and his agents who have the duty of preparing and presenting the case, with knowledge of all seemingly pertinent facts related to the charge which are known to the police department who represent the local subdivision that has jurisdiction to try the case. ${ }^{134}$ The responsibility of the prosecutor is limited to knowledge held by these local officers. Thus, while it is frequently stated that deliberate suppression of evidence by the prosecution will vitiate a criminal conviction, the meaning of the term "prosecution" in these cases has varied; in some cases the term has been limited to the trial prosecutor and those law enforcement officers within the governmental unit over which that prosecutor has jurisdiction, while in others the "prosecution" has been held to include those police agencies of the state directly involved in the investigation of the case. Unconnected out-of-county officers generally have not been included. That there remains lack of decisive direction by the Supreme Court in this particular is evidenced through language drawn from the first United States court of appeals decision in Johnson $v$. Bennett..$^{35}$ A sheriff from an area outside the county wherein the accused was being tried was charged with suppression of valuable defense evidence. The court of appeals observed: "An interesting question is raised as to whether 'the prosecutor' is chargeable with the suppression of evidence for which the sheriff of another county of the state, apparently having no

$=239$ Md. 458, 470, 212 A.2d 101, 108 (1965).

IId.

sId.

\$386 F.2d 677 (8th Cir. 1967), vacated. 393 U.S. 253 (1968), rev'd. 414 F.2d 50 (8th Cir. 1969). 
connection with the prosecutor, is responsible. We need not reach such problem here ....".36

The difficulty with any rule in this field which would not penalize suppression by out-of-county officers is its potential for abuse. Especially in deliberate suppression cases, invalidating the conviction appears appropriate. The law of confessions provides an interesting comparative analysis, for it cannot be seriously contended that a confession, brutally extracted from an accused by sheriff's deputies outside the county of trial, could be held admissible simply because the police or prosecuting attorney of the trial county did not assist in the brutality. In contrast, misconduct by remote police officers in the suppression of evidence field could run unchecked under the judicial approach indicated in specified suppression cases. ${ }^{37}$

A final problem in this area involves passive omission as opposed to willful misleading of the defense. Perhaps out-of-county officers have exculpatory documents in their possession which would prove extremely helpful to a defendant, but which have not been requested by that accused. The police in possession may be unaware of the

\footnotetext{
${ }^{36} / d$. at 681 . A variation on this theme might involve suppression by federal officers of evidence helpful to an accused who is being tried in state court. Where both state and federal officers are involved in the investigation of a case, c.g.. Miranda v. Arizona. 384 U.S. 436, 494-95 (1966), federal authorities would be alerted to the defendant's need for helpful or exculpatory information in the federal files, and an obligation to disclose would appear to arise. Where federal officers have not been involved in the investigation or apprehension a more difficult situation presents itself. Under the "dual sovereignties" approach strong arguments could be forged against overturning state court convictions because of nondisclosure perpetrated by another sovereign. Although the separate sovereign notion has been weakened in recent years, se' Murphy v. Waterfront Comm'n. 378 U.S. 52 (1964): Elkins v. United States, 364 U.S. 206 (1960); L. Hall. Y. Ka.Misar. W. La Fave, J. IsRali.. Modern Criminal Proceddure 1213 (1969). it may yet have application in the suppressed evidence field. Perhaps a workable approach in this area might be to permit the individual defendant's interest to prevail on a case-by-case basis where the undisclosed evidence is highly material, consistent with the emphasis of recent cases that new trials should be granted not to punish prosecutors but to achieve fairness in the trial of the accused. See note $48 \mathrm{ill} / \mathrm{ra}$

${ }^{37}$ This approach appears to preserve a sort of "silver platter" rule in the suppression of evidence field. That rule allowed federal prosecutions to profit from improper conduct of nonfederal police agencies. If state police officers illegally searched a suspect's premises and uncovered proof of federal crime, the proof could be turned over to federal officers on a "silver platter" and used in evidence free of illegal search objections. The doctrine was utlimately destroyed in Elkins v. United States, 364 U.S. 206 (1960). Under the view articulated by some authorities, a prosecutor similarly can try a criminal case free of objections that relevant evidence was suppressed if such suppression is accomplished solely by out-of-county officers. Other courts may recognize the impropriety of suppression by these officials, but may require demonstrations of materiality of the suppressed proof before granting relief even in the deliberate suppression cases. Set authorities cited notes 13, 20, $230 \mathrm{supra.}$
} 
value of the documents. In such cases, where important evidence has not been volunteered, insistence by reviewing courts that the defendant demonstrate a high degree of materiality of the undisclosed proof before granting relief appears justified. Absent willful wrongdoing, a conviction should not be unsettled unless the evidence in official hands could have been put to substantial use by the defense. But the defense should be allowed a chance to make this showing. Any rule which would deny the defendant an opportunity to do so on the ground that the erring police were remote officials appears inconsistent with the constitutional right to a full and fair trial.

\section{False Evidence}

Does a conviction based upon perjured testimony violate due process of law, absent accompanying proof that there was prosecutorial knowledge of or complicity in the perjury? Put differently, can a defendant overturn a conviction on federal constitutional grounds if he lacks evidence of governmental connivance in the false testimony?

The cases, badly split on this question, have arisen primarily in habeas corpus proceedings. One line of authority holds that due process must condemn with "equal abhorrence" a conviction based upon false evidence either known or unknown to the prosecutor ${ }^{38}$

\footnotetext{
${ }^{38}$ A leading case supporting this view is Jones v. Kentucky, 97 F.2d 335 (6th Cir. 1938). Defendant was convicted in state court of murder upon the testimony of two witnesses, one of whom testified as to the decedent's dying declaration. New evidence was presented in a federal habeas corpus proceeding indicating that the witness who allegedly heard the dying declaration was not in fact present at the demise of the deceased and did not have knowledge of the matters to which she testified. The Court of Appeals for the Sixth Circuit noted that the infirmity of the trial evidence was not disclosed until after conviction, and that court's decision dealt with the problem of false evidence in criminal trials wherein the falsity is unknown to the prosecuting officers. The court concluded that due process must condemn with "equal abhorrence" a conviction based upon false evidence either known or unknown to the prosecutor.

Relying upon the Jones case, a federal district court in United States ex rel. Montgomery v. Ragen, 86 F. Supp. 382, 390 (N.D. 11l. 1949), freed a prisoner 25 years after his original conviction, summarizing as follows:

The facts in this case present a situation almost identical with that before the court in the case of Jones v. Conmon wealth of Kentuck!. 6 Cir., 97 F.2d 335. In both cases, petitioners werc convicted and had served a substantial portion of their lives in the penitentiary. In both cases the perjury at the trial was first discovered by the convicted persons many years after the trial. In both cases the perjured testimony was vital to the prosecution's case. . . . In a case of this nature one would not expect to find direct proof of the connivance of the prosecution in the use of perjured testimony, and the
} 
Opposing this view are those decisions which require knowing use of false evidence by the prosecution before any constitutional objection to the conviction can be lodged. ${ }^{39}$

A serious defect in the latter approach may be illustrated. Upon his trial for murder the defendant is placed at the scene of a homicide, gun in hand, by an eye witness. He is also connected to the crime by other incriminating proof of lesser quality. Defendant is convicted of first degree murder and sentenced to death. His conviction is affirmed on direct appeal. A few weeks later the eye witness to the homicide is again walking in the neighborhood where the murder occurred and sees a man walking in the opposite direction who somewhat resembles the defendant. Upon taking a closer look the witness is convinced that it is this man, and not the condemned person, who perpetrated the homicide. The now firmly

circumstantial evidence presented is as strong as could reasonably be expected. However, even if this evidence of knowing use of perjured testimony was not in the case, 1 believe that even on the authority of the Jones case, this petitioner should be discharged. Id.

Sec also Durley v. Mayo, 351 U.S. 277, 291 (1956) (Douglas, J., dissenting).

${ }^{30}$ See Imbler v. Craven, 298 F. Supp. 795 (C.D. Cal. 1969). "[T] he current law in this Circuit, contrary to the holding in Jones v. Kentucky, 97 F.2d 335 (6th Cir. 1938), is that 'knowledge' by the prosecution is required to support a claim of denial of due process bascd upon the existence of prejudicial perjured testimony in a criminal trial." Id. at 807-08. In Taylor v. United States, 229 F.2d 826 (8th Cir.), cerl. denicd. 35 I U.S. 986 (1956), the court held:

Such an issue requires two elements: (I) use of perjured testimony; and (2) knowledge by the prosecuting officials, at the time the testimony was used, that it was perjured. The latter element is a requisite because the fact that there may be false testimony does not alone and of itself vitiate a judgment. Ryles v. United States, $10 \mathrm{Cir} ., 198$ F.2d 199, 200. Id. at 832 .

Several decisions have not gone further than the principle of Mooney v. Holohan, 294 U.S. 103 (1935), that the prosecutor's knowing use of perjured evidence violates due process. E.g. Marcella v. United States, 344 F.2d 876, 880 (9th Cir. 1965), cert. denied. 382 U.S. 1016 (1966); Green v. United States, 313 F.2d 6, 8 n.2 (Ist Cir.), cert. denied. 372 U.S. 951 (1963); In re Sawyer's Petition, 229 F.2d 805, 809 (7th Cir.), cert. denied. 351 U.S. 966 (1956); United States v. Spadafora, 200 F.2d 140, 142 (7th Cir. 1952); Wild v. Oklahoma, 187 F.2d 409 (I0th Cir. 1951); Hinley v. Burford, 183 F.2d 581 (10th Cir. 1950); Tilghman v. Hunter, 167 F.2d 66I, 662 (I0th Cir. 1948); Hysler v. State, 146 Fla. 593, I So. 2 d 628 (I94I), alldd. 315 U.S. 411 (1942): People v.. Robertson, 12 N.Y.2d 355, 359, 190 N.E.2d 19, 21 (1963). See Hysler v. Florida, 315 U.S. 400, 413 (1942). Mr. Justice Frankfurter made this statement:

He [the defendant] cannot, of course, contend that mere recantation of testimony is in itself ground for invoking the Due Process Clause against a conviction. However, if Florida through her responsible officials knowingly used false testimony which was extorted from a witness 'by violence and torture, one convicted may claim the protection of the Due Process Clause against a conviction based upon such testimony. Id. 
convinced witness brings his beliefs immediately to the attention of the prosecutor in the case. Can the mistake be corrected? Under the rule adopted by many courts, the answer is no. Without proof that a prosecutor knew he was presenting perjured or mistaken evidence at the time he presented it the conviction is unassailable. ${ }^{40}$

This approach, adhered to by several authorities, seems inappropriate and stultifying. If false evidence contributed materially to a conviction-if it occupied a significant role in the trial record-the conviction should be upset and a new trial accorded the accused. Prosecutorial participation is frequently difficult to prove, even though it actually may be present. In cases "of this nature one would not expect to find direct proof of the connivance of the prosecution in the use of perjured testimony,"4l and it is unrealistic for courts to demand this of a defendant in order to grant him relief.

A viable alternative would permit the defendant to successfully attack his conviction even without proof of prosecutorial complicity in cases where a key prosecution witness recants his trial testimony on the basis of honest mistake, where a vital witness for the state admits he perjured himself in the original trial, or where later evidence disproves trial testimony which was important to the government's case. The generic term "false evidence," used to describe admitted evidence later proven untrustworthy, should include trial testimony which is repudiated in any of the ways

\footnotetext{
"No such circumstance exists in the illustrative situation presented here. The witness was honest in his original mistake, and the prosecutor had little reason to doubt the accuracy of his identification. Mistaken identifications and the fallibility of eyewitness testimony are not unknown commodities in our courts.

"United States ex rel. Montgomery v. Ragen, 86 F. Supp. 382, 390 (N.D. IIl. 1949). This case was cited with approval in Napue v. Illinois, 360 U.S. 264, 269 (1959). In jurisdictions which require a knowing use of false evidence in order to grant relief, there has been some salutary movement toward inclusion of situations wherein the prosecutor should have discovered the falsity of the evidence, even though he claims lack of actual knowledge. Imbler v. Craven, 298 F. Supp. 795 (C.D. Cal. 1969):

While the prosecutor claimed not to have disbelieved these outright lies, he clearly had cause to suspect them. The reckless use of highly suspicious false testimony is no less damaging or culpable than the knowing use of false testimony, and a conviction based upon such evidence must suffer the same consequence.

Although there are no cases directly holding that testimony which should have been known to be false falls within the prohibition against the knowing use of perjured evidence, a number of cases have directed their inquiries based upon the principle. Id. at $807-08$.

Set also McMullen v. Maxwell, 3 Ohio St. 2d 160, 168, 209 N.E.2d 449, 455 (1965). But see Taylor v. United States, 229 F.2d 826, 829 (8th Cir.), cert. denied. 35 I U.S. 986 (1956).
} 
described above..$^{12}$ Reviewing courts should be available to determine whether false evidence was employed on behalf of the state in a criminal trial, ${ }^{43}$ and the materiality of such evidence in the guiltdetermining process. ${ }^{4}$

A rule prohibiting such inquiry unless there is concomitant proof

32That false evidence includes more than perjured testimony is explored in Hamric v. Bailey, 386 F.2d 390. 394 (4th Cir. 1967). United States v. Kaplan. 101 F. Supp. 7 (S.D.N.Y. 1951) indicates that perjury and mistake will be treated alike constitutionally.

Some authorities might contend that perjured testimony should be treated differently than mistaken testimony. In analyzing any such contention, it should be first noted that serious evidentiary problems are often encountered in establishing that perjury marred a witness's trial testimony. Sct'. e.g.. United States v. Polisi, 416 F.2d 573 (2d Cir. 1969). So also it may be difficult to demonstrate mistake by a witness. A way in which this might be approached, however, presents itself in Johnson v. Bennett, 414 F.2d 50. 57 (8th Cir. 1969), r' 13286 F.2d 677. 680 (8th Cir. 1967), wherein certain handwriting testimony which had been presented at defendant's original trial was challenged. Sev also the conflicting expert testimony developed at the original trial and later in habeas corpus in Miller v. Pate, 386 U.S. I (1967). Once the defendant establishes that mistaken evidence was employed against him and that the evidence was material to the government's case, it would appear appropriate for him to obtain relief just as the victim of perjured testimony may do. To grant relief to the perjury victim but deny it to the defendant who is falsely convicted by a witness's honest mistake would be to say: "Defendants, if the witness against you was spiteful or was to gain something by your conviction and therefore lied, you are entitled to justice; however, if he was simply a blundering fellow who honestly believed in his mistaken identification of you, you may stay in jail." Any such distinction appears irrational.

"Even where a witness recants his trial testimony, a judicial determination must be made respecting the veracity of the witness's recantation. This task will inure to the trial judge initially if the recantation is presented in connection with a motion for new trial and to a habeas corpus court if such recanting oceurs at a later point in time. The first step in all such cases is to resolve whether the disputed testimony was in fact mistaken or false, followed by an inquiry as to the role such testimony played in the original trial. See State v. Compiano, 154 N.W.2d 845. 850 (lowa 1967). Sec also United States v. Johnson, 327 U.S. 106, 1 Il (1946): Gordon v. United States, 178 F.2d 896, 900 (6th Cir. 1949), ('rrl. denied. 339 U.S. 935 (1950): Smith v. Warden. 254 F. Supp. 805 (D. Md. 1966).

"Application of the harmless error standard may present too minimal a test in the false evidence cases. S'' ' L. L.. Chapman v. California. 386 U.S. 18 (1967). To unsettle a conviction under its tenets, to upset a judgment whenever there is a reasonable doubt indicating that falsc evidence contributed to the conviction, might not effect a happy compromise between the need to do justice and the desired finality of judgments. The tainted evidence should occupy an important place in the trial record and have contributed significantly to the conviction in order to void the judgment.

On the question of the materiality of tainted evidence and various tests employed, see Miller v. Pate, 386 U.S. 1. 4-5 (1967); United States v. Polisi. 416 F.2d 573. 577 (2d Cir. 1969); Loraine v. United States, 396 F.2d 335, 339 (9th Cir.), cert. denied 393 U.S. 933 (1968); Luna v. Beto, 395 F.2d 35. 38 (5th Cir. 1968), c'crt. denivol. 394 U.S. 966 (1969); Larrison v. United States, 24 F.2d 82, 87 (7th Cir. 1928): United States v. Whitley, 18 U.S.C.M.A. 20. 23, 39 C.M.R. 20 (1968): State v. Compiano. 154 N.W.2d 845 (lowa 1967).

For a recent case applying the harmless error rule to suppressed evidence, rec Jackson $v$. Wainwright. 390 \&.2d 288 (5th Cir. 1968). 
of wrongdoing by the prosecutor or the police appears out of place in modern criminal procedure. First, direct proof on the issue is rare in most cases. Secondly, the prosecutor may be completely innocent of wrongdoing, and the defendant nonetheless denied a fair trial due to the impact on the jury of a mistaken or spiteful witness's testimony. ${ }^{35}$ For these reasons, requiring evidence of prosecutorial immorality as an absolute precedent to habeas relief represents a less than realistic approach to the false evidence problem.

\section{CONCLUSION}

Certain of the problems described in this article merit judicial consideration at the highest state and federal levels. In the United States Supreme Court, while the law has not been left in total disarray in consequence of Giles $v$. Maryland, ${ }^{36}$ neither has there been major clarification. Uncertainty exists concerning whether convictions tainted by false or mistaken evidence are constitutionally supportable in those numerous instances where the trial prosecutor was unaware that false evidence was being used. Also, what rules control police conduct respecting the disclosure of known facts or evidence?

Resolution of these questions is especially significant for the guidance of our habeas corpus courts, which most frequently confront the problems discussed. The suggested direction of such resolution has been treated. The established standard of certain courts, to the effect that a conviction based on false evidence is unassailable unless the defendant can prove a knowing use by the prosecution, ${ }^{17}$ appears inadvisable. Judicial concern in these cases should concentrate on vouchsafing the right of fair trial to the convicted person.$^{38}$ Hedged with appropriate standards requiring the

\footnotetext{
Li. S'c Jones v. Kentucky, 97 F.2d 335 (6th (ir. 1938).

"386 U.S. 66 (1967).

"Sic'. c.g. United States v. Jakalski. 237 F.2d 503. 504-05 (7th Cir. 1956). c'rr. de'mıtl. 353 U.S. 939 (1957): Taylor v. United States, 229 F.2d 826. 829.833 (8th Cir.). corl. dinied 351 U.S. 986 (1956); Hinley v. Burford, 183 1..2d 581 (10th Cir. 1950): Imbler v. Craven. 298 F. Supp. 795. 807-08 (C.D. Cal. 1969). In Hysler v. State. 146 Fla. 593. I So. 2d 628 (1941), all'l. 315 U.S. 411 (1942). the Hlorida Supreme Court stated: "Writ of error coram nobis will not lie because of false testimony given at trial by important witness. . . . The allegations of the petition do not show .. . that the alleged falsity of the testimony of the witness Baker was known to the prosecuting officer." Id. at 594, I So. 2 d at 628.

"Salutary movement in this direction has occurred at the Supreme Court level. Important language in Brady v. Maryland, 373 U.S. 83 (1963) illustrates that the due process mandate in these cases "is not the punishment of society for misdeeds of a prosecutor but avoidance
} 
defendant to demonstrate materiality of the tainted evidence, the more liberal approach advocated here would threaten only those final judgments which merit unsettlement.

In the field of suppressed evidence, most of the commentators conclude that suppression by police or prosecutors violates the due process mandate. ${ }^{99}$ Certain case authority indicates only partial support for this conclusion, however, reserving judgment where suppression of evidence is perpetrated by law enforcement officers of the state who are only marginally connected with the trial prosecutor. It is here contended that "state action" includes misconduct by police officers of the state who are employed either by the governmental subdivision which is prosecuting the defendant or another: "[I]t thus makes no difference which agency of the state violated due process. . . . Constitutional responsibilities may not be avoided by carving out small units." 50 Governmental action is present and equally harmful whether local or remote law enforcement officials suppress material evidence, evidence which the defendant could put to some substantial use.5t

of an unfair trial to the accused." $/ d$. at 87. For a recent application of Brady: see People v. Sumner, 252 N.E.2d 534 (Ill. 1969). See Jackson v. Wainwright, 390 F.2d 288, 295 (5th Cir. 1968); Ingram v. Peyton, 367 F.2d 933, 936 (4th Cir. 1966); 74 Yale L.J. 136, 142 (1964).

${ }^{3}$ Everett, Discover1 in Criminal Caser-In Search of a Standard. 1964 DUKE L.J. 477, 51617; 1969 L. \& Social Order. supra note 20; 42 N.Y.U.L. REv. 764, 766 n.20 (1967). The conclusion is buttressed by the result reached in Barton v. Wainwright, 412 F.2d 229 (5th Cir. 1969), which held it a constitutional violation when the record demonstrated suppression of witnesses by a Florida sheriff. See also authorities cited note 21 supra.

${ }^{50}$ Levy, Justice-After Trial. 11 N.Y.L.F. 240, 292 (1965). The fourteenth amendment governs "any action of a state. "whether through its legislature, through its courts, or through its executive or administrative officers." " Mooney v. Holohan, 294 U.S. 103, 113 (1935). In a landmark survey of the criminal discovery problem, the propriety of imposing sanctions for police as well as prosecutor misconduct in the suppression of evidenee cases appears to have been suggested. Everett, supra note 49:

In Brady: Vapue. and -4/corla. the prosecutor had participated in withholding or suppressing evidence favorable to the defendant. What if, however, the prosecutor is unaware of the evidence favorable to the defendant because that evidence has also been withheld from him by the investigators? In other words, should the principle of Brady. be affected by the identity of the' governmental agent who "helps shape a trial that bears heavily on the defendant?" The actions of investigators in obtaining coerced confessions have led to reversal on due process grounds of the convictions resulting from those confessions. Would and should their actions in withholding evidence lead to any different outcome? Id. at 516-17.

${ }^{s 1}$ For a most recent case assessing the requisite dimensions of prosecutorial nondisclosure which will mandate a new trial for the accused, see United States v. Polisi, 416 F.2d 573 (2d Cir. 1969). 
Instances of suppression or falsification of evidence hopefully comprise isolated and infrequent features of American justice..$^{52}$ However, when convictions tainted by either of these maladies do arise, our legal system must provide workable rules to effect prompt cure..$^{53}$ The need for such rules is perhaps best illustrated by the extended struggle of prisoners with meritorious claims to attain judicial relief. ${ }^{54}$

${ }^{52}$ Movement to more liberalized discovery in our courts will doubtless assist in the challenge of eliminating in advance well-founded claims of suppressed evidence. See State v. Eads, 166 N.W.2d 766 (lowa 1969); State v. Cook, 43 N.J. 560, 206 A.2d 359 (1965); ABA ProJeCT on Minimum Standards for Criminal Justice. Standards Relating to Discovery and Procedure Before Trial 15, 30 (1969); Carter, Suppression of Evidence Favorable to an .Accused. 34 F.R.D. 87 (1964); 6 DUQUESNE L. REV.. supra note 16.

${ }^{5}$.Se' a Ba Project on Minimum Standards for Criminal Justice, Standards Relating to Post-Conviction Remedies 31-39 (1967).

${ }^{3}$ Sec United States ex rel. Montgomery v. Ragen, 86 F. Supp. 382 (N.D. Ill. 1949), which invalidated the 25-year-old conviction of the prisoner after finding "[t]hat the wrongful suppression by the prosecution of evidence which unquestionably would have established the innocence of James Montgomery was a denial of due process in violation of the Fourteenth Amendment . . . ." Id. at 391 .

In Johnson v. Bennett, 414 F.2d 50 (8th Cir. 1969), a 35-year-old conviction was overturned. While the decisive issue centered on a burden of proof question, Judge Blackmun's wellconsidered opinion alluded to the false and suppressed evidence problems:

The integrity of Johnson's trial and conviction remains seriously clouded by the allegations, seemingly not now controverted, of a sheriff's erroneous, if not false, report and return as to the whereabouts and unavailability of an actually available but imprisoned defense witness, and of the state's use of handwriting evidence now conceded questionable even by the state's own present expert. Id. at 57 .

The Johnson case had been presented in state as well as federal habeas corpus during previous years, but it was only the final series of appeals which brought the described result. See Johnson v. Bennett, 386 F.2d 677 (8th Cir. 1967) (decision by three-judge panel adverse to prisoner), vacated. 393 U.S. 253 (1968) (remanding case for reconsideration), rev'd. 414 F.2d 50 (8th Cir. 1969) (8-0 en banc decision in favor of petitioner).

See also the controlling legal rule applied to deny relief in Hinley v. Burford, 183 F.2d 581 (10th Cir. 1950); United States v. Kaplan, 101 F. Supp. 7. 11-13 (S.D.N.Y. 1951). 


\section{.}

